\title{
Psychodynamics from the Perspective of Non-family Employees during a Small Family Business Succession
}

\author{
Sari Savolainen \\ Department of Business Administration, Savonia University of Applied Sciences, Finland
}

Received November 29, 2019; Revised April 2, 2020; Accepted April 19, 2020

Copyright $\bigcirc 2020$ by authors, all rights reserved. Authors agree that this article remains permanently open access under the terms of the Creative Commons Attribution License 4.0 International License

\begin{abstract}
This study analyses changes in non-family employees' psychodynamics during the family business succession process. Based on the main principles of human psychodynamics and from a non-family employee's perspective, this study examines how changes implemented in a family business succession influence the daily interaction between family owners and non-family employees. The study has been implemented using qualitative research methods and analysis of reached information was analysed by hermeneutic analysis. Based on case study approach this study has found that employees can influence the planning and the implementation of succession but are not actually the direct participants in this process, which is reserved primarily for the new owner/successor. It is important for the employees' psychodynamic process that they are given information about the succession and the information they are given is acted upon in the manner in which it was originally described. If non-family employees can express their thoughts and possibly influence the implementation of changes, that could lead to an improvement of their overall psychodynamic balance as it relates to the family business. The psychodynamic balance affects the employees work well-being and motivation. If employees are given information that differs greatly from the actions that are implemented within the family business that increases the need to balance the psychodynamic process and further decreases the employees sense of work wellbeing and motivation.
\end{abstract}

Keywords Succession, Interaction, Psychodynamics, Information Processing, Non-family Employee

\section{Introduction}

Family business succession literature has almost totally neglected the process from the perspective of employees.
To date, the literature has tended to focus on studying the family perspective because of the type of control that traditionally exists within family businesses (Collins, 2011). As mentioned by Chua, Chrisman \& Sharma (2003), there is a need to contribute to the non-family employee literature. Literature concerning non-family employees has not advanced in recent years and yet it could offer opportunities towards greater understanding of a family businesses' human capital (Sonfield \& Lussier, 2009). This study answers that call by Chua et al. (2003) and Sonfield et al. (2009) by studying the psychodynamics of non-family employees during small family business successions. The aim of this research is to study non-family employees' perceptions through multiple case study analysis. As has been documented, the well-being of employees' influences productivity (Kalimo \& Toppinen, 1999) which can be at risk when succession occurs while succession also has an influence on the profitability of a family business. (Molly, Laveren \& Deloof, 2010, Davis \& Harveston, 1998).

In small family firms, participants interact very closely with one another so when family business succession occurs, it can result in many different kinds of changes (Handler, 1994; Miller, Steier \& Le-Breton-Miller, 2003; Brockhaus, 2004), which impact all those associated with the business, both direct actors and indirect actors (Morris, Williams \& Nel, 1996). The basic concepts of psychodynamics are that human behaviour is the consequence of 'mind movements' as well as the interaction with the environment. It also explores how the mind stimulates human behaviour, examines the interplay between mind and behaviour, and finally how the social environment affects the human mind (Payne, 2005; Howe, 2002). Along with analysing the factors that affect human behaviour, modern psychodynamics is concerned with how people interact with each other in the 'social world'. Furthermore, it highlights the meaning of emotions and how a person connects with him/herself, involving past and present experiences and between internal and external 
reality. (Brearley, 2007).

Family businesses differ from non-family firms especially from the viewpoint of group level psychodynamics. Ruggieri, Pozzi \& Ripamonti (2014) concluded that family managed businesses and family ownership can be seen as a whole integrated system, wherein the same actors play their role while referring to a shared symbolic order (local culture, as defined), which entails both cognitive and affective direction. Further variables such as family involvement with the business, family management, family ownership and trans-generational sustainability are issues that can introduce bias in the resource evaluation process and influence the way resources are accumulated or divested within family businesses (Kellermanns, 2005). Psychodynamics influences the decision-making process around specific issues that impact family firms such as ownership dispersion among family members, altruism, control concentration, family employment and succession (Kellermanns \& Eddleston, 2004; Chrisman, Chua \& Steier, 2002; Chua, Chrisman \& Sharma, 1999; Gersick, Davis, Hampton \& Lansberg, 1997).

It has also been shown that a family business succession can bring about different kinds of tensions and pressures. Family psychodynamics can influence both the parents and their offspring (Miller, Steier \& Le Breton-Miller, 2003), which in turn can lead to siblings fighting for priority from their parents or parents ending up favouring one sibling over another. In cases like 'family worship', the 'golden cage' or the fight for control, there is a noticeable retreat from the symbolic family order with the web of relationships within the family taking the leading role. During this process, the gradual building of the successors' leadership and skills are less represented (Ruggieri, Pozzi \& Ripamonti, 2014; Salvato \& Corbetta, 2013). Research has found that family firm predecessors are neither very cooperative nor open because they don't like to share business information with others which in turn restricts the firm's growth and performance (Kets de Vries, 1997; Mintzberg, 1994). In contrast, high-performing family firms encourage all members of the organisation to participate in developing long-term goals and strategies (Upton, Teal \& Felan, 2001). Furthermore, family business leaders in high-performing firms tend to share their goals and strategies with employees on a regular basis.

So far, we know how the relationships between family member's and behaviour are connected to family business succession. We know the meaning of family values to family business success and how those values bring along both positive and negative influences in terms of performance and the success of the business (Molly, Laveren \& Deloof, 2010, Davis \& Harveston, 1998). We are aware that family business succession is a transition of the entire family organisation rather than a simple rotation of management and ownership (cf. Handler, 1994). That is why it is important to compare the connections of all participants to the changes that occur within the family and the firm, because family business succession often means addressing issues of co-existence between different generations and participants who have been involved in the family business. Family business succession should not be seen as a single event in the life circle of a family firm but more like a cyclic event occurring intergenerationally (Ruggieri, Pozzi \& Ripamonti, 2014).

Family business succession still needs scholars to compare all parties during and after the structuring of a new form of organisation, and to analyse how the creation of a new culture can be utilised and harnessed for the benefit of the business by those both inside and outside the family unit. This study aims to fill the gap in our knowledge around how changes in psychodynamics influence the behaviour of family and non-family members. As mentioned previously, the experiences of non-family employees have not been sufficiently studied; we still have much to learn about how non-family employees' experiences help influence both the success of family firms during succession and the impact on the overall performance of the family business. This study is inductive, and its nature is explorative. It creates a new theory about phenomena of real life and that is why qualitative approach in this study was the most suitable (Welch, Piekkari, Plakoyannaki \& Paavilainen-Mäntymäki, 2011; Yin, 1994). Through a qualitative research method, this study sought to answer the following research questions: How does family business succession affect the mindset of non-family employees as well as examining the impact on their behaviour and attitude towards their environment? Which kind of psychodynamic reflections has an employee to the social environment within a family business?

\section{Literature Review on Psychodynamics}

\subsection{Psychodynamics and Its Characteristics}

Psychodynamics is based on the work of Sigmund Freud and his adherents. The basic rule of psychodynamics is that human behaviour is a result of mind actions and interactions with others. Psychodynamics highlights how the mind stimulates behaviour, the interaction with the environment, how the mind stimulates human behaviour, the interplay between mind and behaviour, and finally how the social environment affects the human mind (Payne, 2005; Howe, 2002). In addition to that mentioned, modern psychodynamics is interested in behavioural factors for example, how humans interact with each other in the 'social world'. In terms of this research, that 'social world' is the family business environment during succession. Furthermore, Brearley (2007) highlights in modern psychodynamics the importance of emotions and how those emotions interact between self and other, present and 
past, internal and external reality.

Human interaction and psychodynamics are an important part of management and organisational behaviour. In human management literature, psychodynamics relates most to development of personality (Kets de Vries, Vrignaud, Korotov, Engellau \& Florent-Treacy, 2006) as well as organisational identity and learning (Brown \& Starkey, 2000). Furthermore, it links to such concepts like CEO personality (Nadkarni \& Hermann, 2010), change agents and human networks (Battilana \& Casciaro, 2012), good employee citizens in different kinds of human relationships within organisations (Anand, Vidyarthi, Liden \& Rousseau, 2010). Common to all those concepts is that they are related to human thinking and the relationship environment between people in organisations.

Behind psychodynamic theory is self psychology (Cushman, 1990) an individual's self-experience and relation to self, to his/her environment are present as well as identity as personality. The human self is constantly changing and consists of several different features such as: early experiences, memories, values, etc. (Jonides, Lacey \& Nee, 2005). Personality psychology has shown that from the five big personality features, three (extrovert, amicability and emotional stability) look to support the development of general trust and openness when it comes to human interactions (Ignatius \& Kokkonen, 2005). The forming of the complete self-experience and identity affects those principles as the person directs their own behaviour and develops self (Cushman, 1990). For example, from the viewpoint of self-psychology and object-relationship theory, it is possible to find inside the human mind, mental actions and a desire to gain control of the psychic wholeness in self-experience (Kohut, 2009).

\subsection{Psychodynamics Observations from Environment and Experiences}

The human mind divides into two different levels that of conscious and unconscious. That division is the central factor behind several psychological phenomena like information forming, self-experience or thinking (Piaget, 1926; Hayek, 1952; Beck, 1985). Human conscious self-perception can be distorted because a person stores rejected and threatening material like emotions and thoughts to the unconscious memory (Jonides, Lacey \& Nee, 2005). Moreover, humans have a consistent tendency to act reasonably because of a natural need to maintain 'mind balance' (Tang \& Posner, 2009). In essence, the human mind tries to move away from a disturbed or chaotic order to reach more balance and have a continuing complete experience with self (Cushman, 1990; Kohut, 2009). In this study, especially meaningful from the viewpoint of psychodynamics, is how the human mind forms and stores information to both the conscious and unconscious mind as well as how it interprets perceptions associated with different kinds of situations. One of the objectives of psychodynamics is to understand the human mind and it actions, and to form a connection between the concept of psychodynamics, human consciousness and the surrounding world (Maiteny, 2002).

Human information forming in relation to the surrounding world is based on cooperation of our conscious and unconscious mind, which forms a hermeneutic circle (figure 1) (cf. hermeneutic of science, e.g. Easton, 2010; Sayer, 2000). In that mind process, new observations from the environment are joined together with pre-understanding formed by earlier observations and experiences (Anderson \& Goolishian, 1992; Fruggeri, 1992).

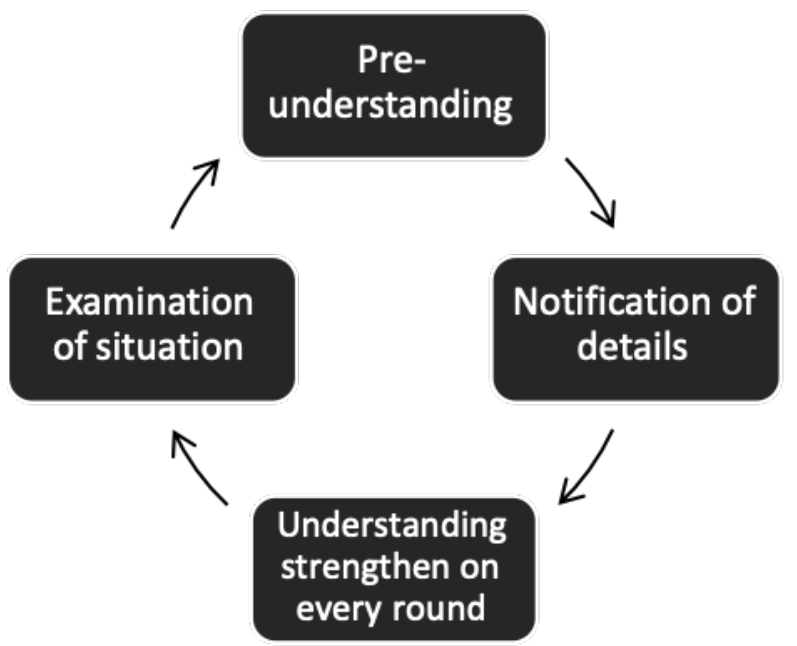

Figure 1. Hermeneutic circle of information forming (cf. hermeneutic of science, e.g. Easton, 2010; Sayer, 2000)

Human senses make observations all the time about the environment, even in relation to such issues that are not active in the mind at that moment. Even when a human mind is concentrating on something in particular, the senses are continuously aware, observing (data forming) and filing that information in the unconscious mind (Meyer \& Damasio, 2009).

Central to the information forming process are interpretations of observations and connecting them with earlier experiences (Baars \& Gage, 2010; Costigan, Ilter \& Bergman, 1998). After instant experiences, observations are recorded to the long-term memory separate from the conscious mind (e.g. Meyer \& Damasio, 2009).

For the conscious mind, thinking is active and immediate while memories and recollections are recorded to an individual's memory (Solso, 1979; Saariluoma, Kamppinen \& Hautamäki, 2001). The human mind records details from earlier experiences as well as emotions and reactions. Where the human mind in time will forget details of memories, those recollections and emotions reside longer in the memory (Solso, 1979; Saariluoma et al. 2001). Furthermore, it has been possible to show that thinking guide emotions (Frijda, 1986; Lazarus \& Folkman, 1984; Ortony, Clore \& Collins, 1988) and correspondingly, 
emotions guide information forming and decision making (Albarracin \& Kumkale, 2003; Schwarz \& Clore, 1983).

In cognitive psychology, the concept of hindsight bias is important. It describes a phenomenon in the human mind where a memory forms around some event, which over time develops new interpretations and gives experiences new meaning (Delmar \& Davidsson, 2000). According to recent studies, hindsight bias causes a distortion of recollections, understanding of necessity and predictability of things and situations (cf. Blank, Nestler, von Collani \& Fischer, 2008; Nestler, Blank \& Egloff, 2010; Bernstein, Erdfelder, Meltzoff, Peria \& Loftus, 2011).

\subsection{Psychodynamics \& Thinking}

Thinking affects the meaning an individual creates around observations and information. In the meaning giving process, human subjectively gives meaning and constructs its own behaviour and requirements in accordance with the environment (Meyer \& Damasio, 2009). The giving of meaning to observations and experiences is based on memory structures formed by previous ones (Beck 1985, Brewin, 1996begin_of_the_skype_highlightingend_of_the_skype_ highlighting). Meaning giving is a phenomenon of the mind and by giving meaning an individual relates him/herself to the world and understands the world sensibly and as a manageable entity (Beck, 1985).

According to Piaget (1926), thinking's basic forms rest on the constructive interpretation of meaning, in that human thinking and information forming is based on action and interaction where a person adapts to his/her environment and its principles. In his theory, Piaget combines the concepts of accommodation and assimilation to commitment. In assimilation, a person adapts to the principals of the physic and social environment in order to develop a form of thinking that makes it possible for him/her to survive in the world. Correspondingly, accommodation describes human thinking and the interpretation of the world, which is needed to analyse and possibly reform the schematic structures of the mind. Schemas (Beck, 1985) fulfil and adapt to the physic and social world where a person lives and acts. A person observes the world in that it is the target of his/her conscious actions, as a result of both thinking and observing an action, the thinking and action is both influenced and directed (Beck, 1985; Snow, Corno \& Jackson, 1996).

Psychodynamics is based on each individual's mind model, for example, ways to handle observations and how to relate to the surrounding environment. In this research, the surrounding environment refers to small family firms that are going through a family business succession while individuals mind models will be examined in the context of changes caused by the succession process. In terms of each individual's mind model, three different experiences are important for psychodynamics: mirroring, idealisation and twin-ship (Kohut, 2009). Mirroring means how you reflect yourself to others, idealisation is the proportion of idolisation of an individual by others, and twin-ship concerns the feeling of cohesion. These three are important because through them a person constructs a basis for self-existence and sense of similarity with other people. The quality of experience affects the forming of self-experience, because the life principles of an individual relate to self-ideals and values which form from each individual own early mirroring experiences with other people.

Human development and operations are affected by a number of different factors such as the environment, where a person acts, which kind of social relationships exist in the environment he/she has and how a person relates to him/herself. All aforementioned factors impact on what kind of mind a person has, how their thinking forms and how it will affect his/her behaviour and attitude in various situations. Human interaction is never one-sided; interaction reflects on each other and will affect the quality and form of interaction of other participants.

\subsection{Psychodynamics, Management and Organisational Behaviour}

Psychodynamics in management is connected strongly to organisational behaviour and that is why it has influenced organisational management and the success of management actions (Vince, 2011; Schneier, 1974). Modern psychodynamics is concerned with how people interact with each other in the social world (Payne, 2005; Howe, 2002) and with work interactions that occur within organisations. Management actions and organisational changes are situations where different individuals, their identities and personal goals come easily into conflict. Brown \& Starkey (2000) state that from a psychodynamic perspective, organisational learning involves understanding and mitigation of ego defences that tend toward regressive retreat from a changing reality. Furthermore, they state that management's role is to promote mature and adaptive thought and action in pursuit of collective organisational good. Where management is not able to create a good relationship in the workplace, poor workplace relationship can enhance situations where individual employees negotiate specific arrangements for themselves with their employers (Anand, Vidyarthi, Liden \& Rousseau 2010).

Psychodynamics is connected to an employees' cognitive processes (Brown \& Starkey, 2000), which means that an employee's previous experience influences his/her capabilities in terms of handing new and strange things or happenings in life. According to Brown \& Starkey (2000), a psychodynamic perspective to organisational identity and learning argues that organisational learning can be held back by the 
organisations efforts to preserve its identity. In organisations every person or group, each entity needs at least a preliminary answer to the questions: "Who am I?" or "Who are we?" in order to interact effectively with other entities in the long term (Stuart, Ashforth \& Dutton, 2000). According to Brown \& Starkey (2000), from a psychodynamic perspective there are no straightforward solutions when it comes to issues around changing identity especially in terms of an individual's unconscious defence mechanism. Individuals and organisations defend their existing identities and that way reduce their opportunities to learn or adapt to changes in the environment. The underlying task in the management of groups and organisations is the same from a psychodynamic perspective: to create an emotional climate where individuals are able to balance the need to feel they belong to a group without losing their individual identity so that they can work towards organisational goals that improve their self-esteem.

\section{Methodological Choices of the Research}

\subsection{Case Study Approach}

The case study approach used in this research paper aims to derive conclusions from a limited number of cases (Yin, 1994). While studying processes and exploring meanings, this case study method helps researchers to answer questions such as how and why, by using those involved as a reference point, as opposed to relying on predetermined solutions (Cater and Justis, 2009, 112). This research seeks to learn from what already exists and to provide a description of the phenomenon. The stories from participants were collated as well as any observations that were made in relation to the goal of the research. The purpose of the hermeneutic function analysis in this case is to stimulate exploration by interpreting the research subject and by describing succession characteristics. This study also contributes to the mental process and its role during succession. This research is a multiple-case study, as it involves three cases. The selection of cases was based on a pre-consideration of the situation in each case. The logic underlying the use of multiple case studies is the same. Each case had to be carefully selected so that it either predicts similar results or produces contrasting results but for predictable reasons. In this case, selection was based on selecting firms with similar characteristics for the research setting.

\subsection{Informants}

This research adopted the following approach to each case study: we contacted prospective small family firms and first ascertained if the firm had the necessary requirement and willingness for a satisfactory research implementation. After receiving positive answers to conduct the interviews, we started to outline a list of subjects that would be handled during the interview. The research plan was written so that a preliminary understanding of the subject was reached. The interviews were qualitative, with open-ended questions and notes on the experiences of other participants about the succession process in family businesses. The primary research data collected was shaped from interviews and supplemented by observing the participants as well as the review of company documents. All the companies represented different fields of business. One of these small family firms was founded in the 1980s and the other two at the beginning of the 1990s. All three companies are founder generation firms, which are facing their first succession. Interviews were carried out in an unstructured format, there was a preliminary list of subjects to handle during the interview while the interviewee answered the open questions. The preliminary list of subjects acted as a guideline and as a checklist for the interviewee.

\subsection{Data Collection}

Data for this research was collected in three different ways. The first part of the data collection was through interview. Interviews were conducted individually, totalling 14 participants: 3 from each case. The length of the interviews varied between 20 minutes and 70 minutes. All interview material was recorded on tape, for a total of 10 hours 53 minutes. The transcribed interviews totalled 181 pages. Other observations included the behaviour of the interviewees under interview conditions: their facial expressions, the gestures and the tone of voice. These observations were compared with the voices on the recordings. Furthermore, personal notes were written about the experiences of meeting the participants during the regular working contacts. In addition, similar notes were made before and after the interviews. These have enabled us to explore the data in more depth and also analyse what occurred in the family businesses after the interviews.

\subsection{Analysis of Data}

The conceptual methodology of this research consists of two basic branches: analytical and interpretative. The interpretative branch is designed to reveal meanings behind concepts and their definitions, in such a way as to expand the understanding of those concepts. We can analyse meanings related to the concepts, while the interpretation is linked with contextual factors (Kyrö and Kansikas, 2005, 122). The data collected from this study has been analysed by hermeneutic (Clarke, 1999; Myers, 1997) and abductive analysis methods (Walton, 2007; Josephson \& Josephson 1996, 6). Hermeneutic analysis concentrated on indexing the interviews, which examined the interviewee's stories about their experiences during succession. It also looked at 
what happened and how those events and experiences affected their thinking and relationships. Data was collected from different groups of participants, (founders, successors and non-family employees), which made it possible to compare the different participant stories and their experiences.

Abductive analysis was used alongside the hermeneutic method. It deals with observations from research and theories, comparing and explaining findings. In this research, abductive analysis is important from a phenomenological perspective. Essentially, this research seeks to understand phenomena that occur in daily life. The purpose of the research is not to test some already existing theories through hypotheses, but to achieve an understanding of phenomena and through the findings, shape and formulate some contribution towards the existing theories. Analysis of the data started during the transcription process and continued during the reporting process. Abductive analysis needs continuing alertness and critical thinking about connections, possible explanations and research findings. Researchers have to be able to identify which findings are important for the validity of their research and which findings may be questionable and/or viewed with suspicion or doubt. Furthermore, a researcher has to be able, by use of preceding or existing theories, to argue their own conclusions logically.

\section{Results}

The results of the study show that the bigger the changes implemented, because of succession, the more pressure it means for the employees' psychodynamic balance. Moreover, it is possible to notice that every change brought about by succession causes psychological processing to occur in mind of the employee. Of course, it is easier to accept and adapt to positive change, but what is of more importance is the size of the change. Sometimes large and demanding positive changes bring as much change to the employees psychodynamic as that of a similar sized negative change. Employee's experience of that change will define which direction they see the change taken by the firm. Generally, it is possible to state that employees see positive change as a developing and improving process and correspondingly that negative change will be seen as a threat for the family business and for the continuity of employees' work. Moreover, positively viewed change increases an employee's commitment and work motivation; positive change can have an improving effect on the employee's sense of work wellbeing. On the other hand, negatively viewed change can have the opposite effect.

\subsection{Cases Where Employees Were Not Supported and Left Alone: Individual Level}

Employee case 1: “...they (founder and successor) are both out and we have to manage all daily actions by ourselves......we (employees) don't know if we have done things right or no.....they (founder and successor) give instructions about things we (employees) are already doing for months......we (employees) are all worried about the firms future, because the successor is planning new projects all the time even though previous ones have not yet been finished......all this has had an influence on our work motivation and it is difficult to get up in the mornings and leave for work.....

Employee case 2: "...they (founder and successor) hold a meeting over almost every small thing and it takes time and time...meetings are held on things I was previously able to decide for myself....they don't listen to anyone though we (employees) know how things are happening out in the field...

In studied cases 1 and 2, employees felt that they were left outside the decision-making process and that family members were not interested in their thoughts and visions for the future of the family business. In case 1 , employees had to organise and manage the daily operation of the family business completely alone. Decisions made by the founder and successor were made without any kind of consultation or with the cooperation with employees who were running operations on a day to day basis. Information given to employees about the daily activities was often incorrect or not implemented by the founder or successor.

In case 2, employees reported that the decision-making process during succession took too long and that it affected the daily work. It was felt that the situation led employees to feel worried about the future of the family business. They were not able to trust their leaders and they felt the need to protect their psychological ownership of the business i.e. that sense of belonging to the firm (cf. Savolainen \& Kansikas, 2013). All that increased the need to think about even the smallest daily activity. This further affected the employees' sense of work well-being and work motivation.

A common factor in cases 1 and 2 from the viewpoint of employees was uncertainty and the limited information provided about planned and implemented changes. Incorrect and delayed information forced employees to solve daily problems themselves and that led employees to wonder if their decisions were correct and in line with the interests of the founder and successor. In periods of uncertain or unclear situations, employees started to collect available information from their environment. Psychologically, the mind is such that in strange situations it starts to create predictions about the future based on pre-assumptions, which are more often negative than positive. Limited information, incorrect orders, overlapping decisions of the founder and successor led to situations where employees started to find supporting evidence and information for pre-assumptions which were based on previous experiences. 


\subsection{Cases Where Employees Were Not Supported and Left Alone: Group Level}

Successor case 1: ...we (founder and successor) had such a condition that...like everyone had it assimilated and understood and so on...that we (founder and successor) thought that it was enough when we give instructions.... tell it to them (employees)...

Founder case 2: ...the successor started to wonder, what if an employee will fulfil his threat and resign because of those change which he implemented for succession... yes I noticed that decision making has been problem and it takes time...It was the successors idea to limit the empowerment of employees, he wanted to have more control over what was happening in the firm...but now it looks that there is too much control maybe....

In cases 1 and 2, implemented family business succession had a negative effect on non-family employees' psychodynamics and it directly affected their behaviour and attitude towards their working environment. It also had a corresponding impact on employees towards the founder and the successor in the family business, for instance, employees' behaviour and attitude towards the founder and successor changed. The founder and successor were similarly affected by the change in their employees, becoming more uncertain and it altered their decision making in relation to the implementation of changes following the family business succession.

Founders and successors noticed that employees trust towards them and to the continuity of family business decreased. Employees resisted almost all the changes while successors found that they had a reduced connection to the employees. From these two cases it is evident that the psychodynamics of non-family employees had an effect on the founders and successors psychodynamics and how they ran the firm and the kind of decisions they made. In these two cases, official information was limited and sometimes unreliable, employees as a group started to make their own informal conclusions and decisions. Their conclusions were based purely on their own information about was happening in the family business. They evaluated the behaviour of the founder and successor and from that came to their own conclusions about how trustful they were, in other words, employees altered each other's psychodynamic balance.

\subsection{Case Where Employees Were Supported and Included: Individual Level}

Employee case 3: "I have encouraged successors and said to them that it's great they take care of the continuity of this family firm...succession is positive because it brings along new developments...it (succession) has cheered up the atmosphere in the firm...they (founder \& successors) asked our (employees) opinions about changes...we (all founder, successor \& non family employees) have had official meetings and unofficial events together and we have discussed lots of things and develop the firm together...

Case study 3 contrasted completely with Cases 1 and 2 . In this case, founder and successors (there were three successors) had taken non-family employees into the decision-making process and consulted with them on planned changes. In addition, non-family members were asked to join family meetings when decisions impacted employees' work or position in the firm. The behaviour of this founder and these three successors supported the manner in which employees' treated information and the way they came to conclusions related to that information. In case study 3, employees did not have to make their own conclusions about what was going to happen to the family business they were a part of as they were at the centre of action/decision making. They knew beforehand what was coming and they had been able to give their opinions concerning planning and implementing change related to succession. In this case, employees were able to more easily define their behaviour and relationship to their environment (i.e. the family business), which assisted the interests of the business and helped its continuity.

In this case, employees reported that they felt the atmosphere in the family business changed to one that was more inspiring and refreshing than before succession had started. Employees found they were more motivated and enjoyed working in the firm. In this instance, the family business succession changed their behaviour because of the manner in which it was handled and as a result it also improved their attitude towards their working environment. Information employees received was accurate and on virtually every occasion they knew about events before they happened. The conclusions they made from observing the behaviour of the founder and successors were in accordance with information provided at an earlier stage in the succession process. All actions and events within the firm encouraged the employees to trust the founder and successor from the beginning, which is extremely important because it set the tone for the future relationship between successor and non-family employees which in turn supported the goals of the family business.

\subsection{Case Where Employees Were Supported and Included: Group Level}

Founder case 3: “...employees did their work even better than before...they wanted to do more with successors and cooperate...succession brought positive consequences...they have more responsibility...if they notice there is something we have not been able to do during normal working hours, they (employees) comes to do it even during weekends... Implementation of succession has been fairly easy to us...everybody in the firm has to know what and when things happen... 
In this case, family business succession had a positive effect on non-family employees' psychodynamics. Succession improved employees' attitude towards their working environment and it also reflected positively on other members in the firm. In this particular firm, succession brought about a positive feeling of something being done. Decision making and future planning were much easier for the founder and successors because they received very supportive and encouraging feedback from other members in the firm. In this case, the founder and successors were able to notice that non-family employees trust towards them and the firm increased. The changes the founder and successors needed to implement were relatively easy to make because employees have been informed of all the needs of the family business, of future plans and projects and therefore had enough information from the beginning of the process which enabled them to adapt in time to the new working environment. In this case employees didn't need to arrive at their own conclusions because they all had the proper information, which the behaviour of founder and successors supported.

\section{Discussion}

It is possible to see that family business succession in small family businesses can affect the psychodynamic of all those involved in the family business, which includes customers, suppliers and other actors. In all three cases, the relationship between non-family employees' and the family business changed because of the succession. When employees saw a positive succession with the aspects mentioned above such as inclusion in the decision making, openness and transparency, their thinking about the firm and its future became more positive. On the other hand, when employees saw a succession process which displayed the opposite characteristics, their thinking about the firm and its future prospects became more negative. Family business successions seem to change non-family employees' psychodynamic balance so that they were forced to reform their thinking towards the firm and its leaders. (cf. Payne, 2005; Howe, 2002).

\subsection{Importance of Open Communication and Behaviour}

In psychodynamics, an individual's relationship and behaviour to the existing social and physic environment is based on their own model of inner mind and the way in which they handle observations from their environment. In psychodynamics, this is also a key aspect because attention is paid to how people interact with each other in the social world (Payne, 2005; Howe, 2002). In case studies 1 and 2, where the employee's psychodynamics developed in a negative direction, employees reflected more on their observations about the daily processes in their respective firms and compared them to their previous experiences and memories. Their thought process tried to form new patterns that could identify how current observations related to previous experiences and memories (cf. Piaget, 1926, 1930; Beck, 1985; Snow, Corno \& Jackson, 1996).

The quality of observations from the environment and experiences affect the forming of the employees' self-experience which accord with their life goals, self-ideals and values. Non-family employees' perception making enabled them to compare the level of trustfulness between the original founder and the current successor while also identifying differences in behaviour and approach. (cf. Costigan et al. 1998). According to the results of this study, open communication within the organisation, indicating change in advance and giving adequate time to adapt, all reduced the level of suspicion and tension among employees towards future changes. Such a pro-active approach led to a positive correlation between change experience and employee commitment, work motivation and wellbeing.

In the human mind, observations connect to the individual hermeneutic thinking process, in-turn the thinking process expresses itself in an individual's behaviour. In cases 1 and 2, where information did not match an employees' observations within the family firm, the thinking process led employees to question the accuracy of the information they had received and led them to create predictions about the future, which in these cases were negative. These observations and predictions influenced their attitude which became reflected in their behaviour (Figure 2). 


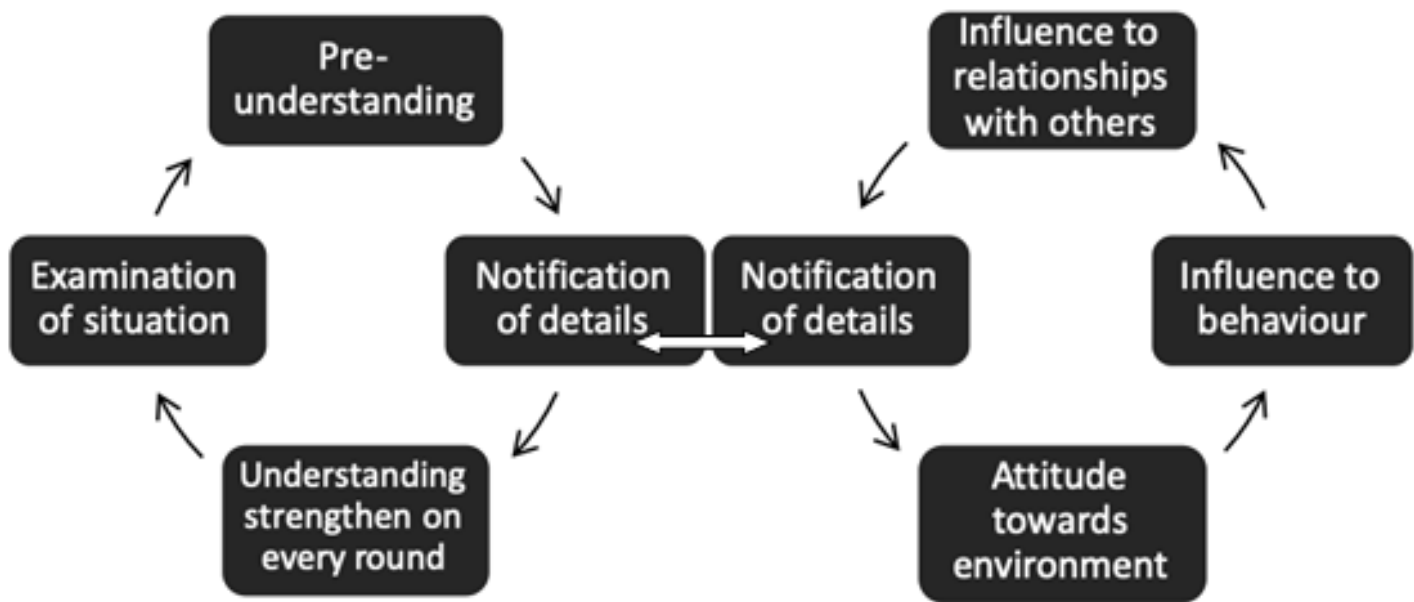

Figure 2. Hermeneutic information loop and psychodynamic loop connection (cf. e.g. Easton, 2010; Sayer, 2000; Payne, 2005; Howe, 2002)

Results from the case studies indicate that changes in non-family employees' psychodynamics and behaviour leads to a corresponding change in the behaviour and impacted the psychodynamic balance of the founder and successors (cf. Payne, 2005; Howe, 2002). Change in a firm often causes pressure for an employee to change their way of thinking which in turn leads to changes in actions. If one employee in a firm changes his/her behaviour it is natural that it will have reflect on the behaviour of others and their future thinking.

\subsection{Employees Psychodynamics Reflects Decision Making and Succession Implementation}

Non-family members quite often think that succession in the family business they work for does not belong to them and as a consequence, they can often feel quite excluded from the process. It also appears that family members, founders, successors felt they did not need to discuss or even inform non-family employees about future events in their firms. The findings of this research indicate that non-family employees, especially in small family firms, are actors in the family business succession along with founders and successors. Non-family employees can impact, both directly and indirectly through their behaviour, on the decisions founders and successors make during the implementation of the family business succession (Figure 3). That employee affect happens partly consciously and partly unconsciously (Payne, 2005; Brearley, 2007; Howe, 2005).

Figure 3 describes the Handler model (1994) and how employees are attached to the predecessor and successor at different periods of the succession-leadership change. The Handler model has been in use for a long time and needs updating. It is too mechanical/rigid and has left out many important parts of family business succession like the role of non-family employees. At the same time, it is very simple and clear when it comes to presenting the various stages of succession. However, results of this study differ remarkably for Handlers model (1994) and the precise steps of changes. Non-family employees who were interviewed said that from their viewpoint, the succession from predecessor to successor was a smooth transition. 


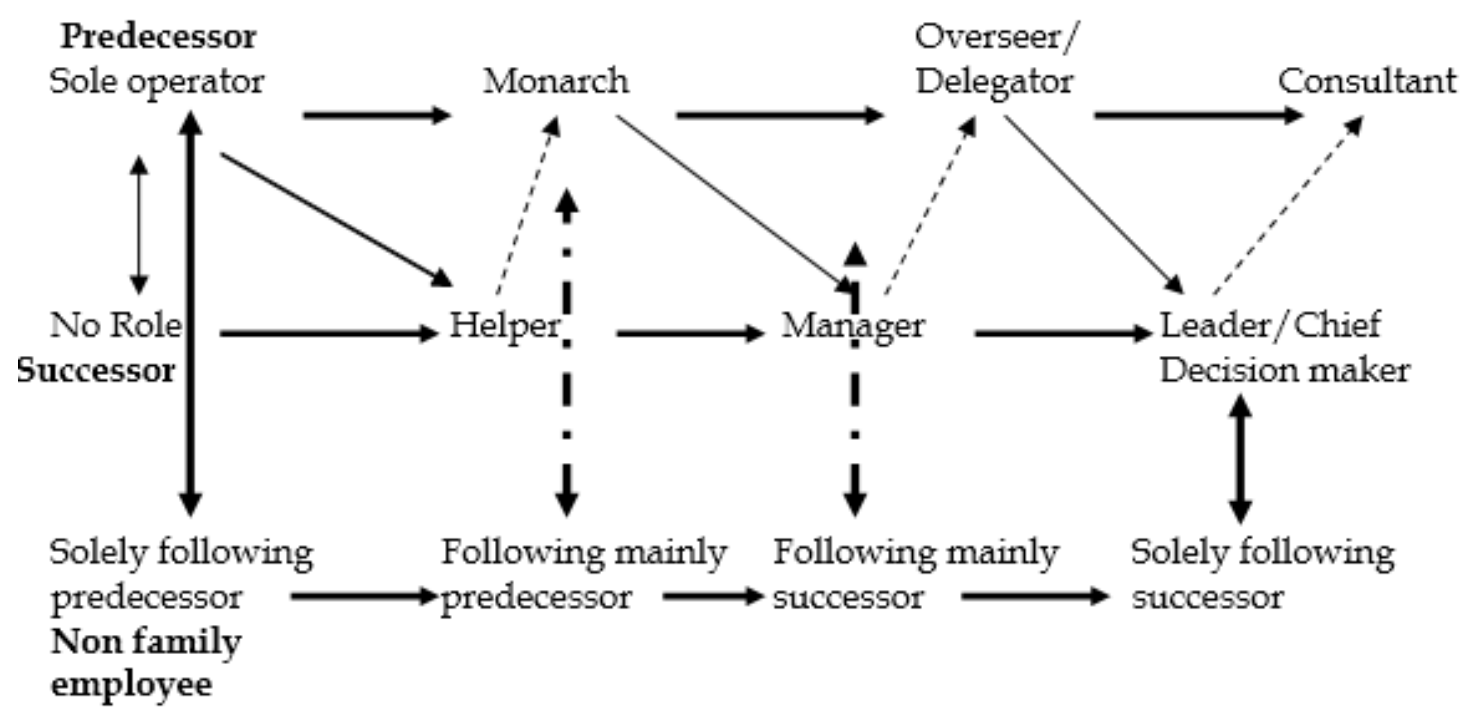

Figure 3. Handler 1994 model added with employee connection

E.g. Employee case 2, “...It was a smooth transition from predecessor to successor...”

Employee case 3, “...I did not see any real steps there at all, we seemed to glide through the succession..."

From the viewpoint of human psychodynamics, these results are very rational. In agreements and statements, we can set precise dates and deadlines for different issues and changes. The ability to adapt and made decisions, agreed details and changes, requires time for consideration of meanings, of agreements and changes along with other psychological adaptation processes. As presented above, thinking and psychodynamics are strongly linked to observations from a person's environment. When an employee observes the implementation of decisions, agreements and changes and sees they are not same as the information given and outcomes forecast, these decisions, agreements and changes won't be taken on board because the thinking and psychodynamics are still connected to earlier practices. When observations and information about decisions, agreements and changes are linear, adaptation to decisions, agreements and changes happens little-by-little within the unconscious mind. The ability to adapt is subjective and the length of time needed varies from individual to individual.

\subsection{Positive Development of Employee Psychodynamics Improves Work Motivation and Increases Commitment}

Human beings have the natural tendency to maintain their 'mind balance' and act reasonably. Furthermore, the mind tries to move away from mind imbalance, disturbing situations or chaotic scenarios and instead reach an ongoing, more stable experience with self. Human information forming is based on the cooperation between the conscious and unconscious mind, where new observations are connected to pre-understanding which has been formed from earlier experiences (Anderson \& Goolishian, 1992; Fruggeri, 1992). Human senses make observations constantly even from issues or situations that are not at that precise moment active in the conscious mind. Even when an individual's action is a totally concentrated conscious action, his/her senses are constantly making unconscious observations about the surrounding environment.

From the psychodynamic perspective, the human mind and its thought process resembles a spinning top, where kinetic energy supports the human minds' conscious and unconscious observations from reality. And like the spinning top, the human mind tries to find balance very quickly. Correspondingly, humans reflect on what is reasonable based on visions of memories and mind structures formed from previous life experiences (cf. Piaget, 1926, 1930; Hayek, 1952; Solso, 1979; Beck, 1985; Snow, Corno \& Jackson, 1994; Brewin, 1996; Håkonsson, Obel \& Burton, 2008).

In the studied cases, changes in employee's psychodynamics had both negative and positive effects and the nature of the effect correlated to the experiences a non-family employee had as a result of the changes caused by implemented succession. All these effects reflected both the employees mind and thinking, and defined their behaviour and attitude towards their surrounding environment, for instance, the family firm, membership in work, role in the community and so on. Changes in non-family employees' behaviour also reflected and affected members of the organisation they were a part of. (cf. Payne, 2005; Howe, 2002).

When the psychodynamic loop is positive (like in case 3) it works at both the individual and group level and helps the family business owners to implement needed changes (figure 4). With positive psychodynamic balance everyone in family firm behaves in such a way that it keeps up others positive psychodynamics. As in case 3 employees were 
included in the decision-making process while predecessor and successors listened to their employee's opinions about planned changes. This positive cooperation supported the employee's ability to adapt to changes and they didn't need to create their own pre-assumptions how things would go in the firm. It is important to note that positive feedback from the employees helped ease the implementation of the succession process by both the predecessor and successor.

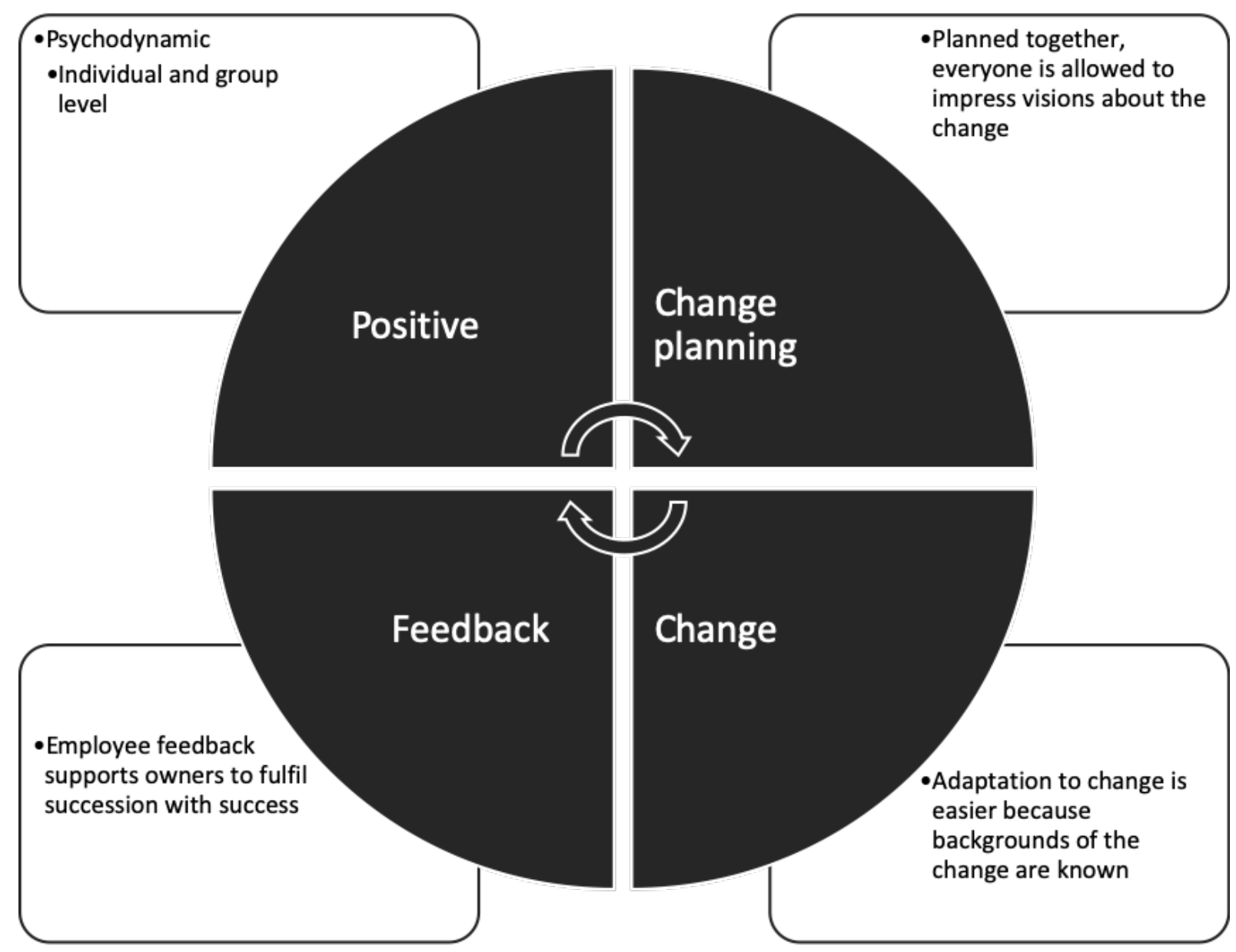

Figure 4. Positive psychodynamic loop 


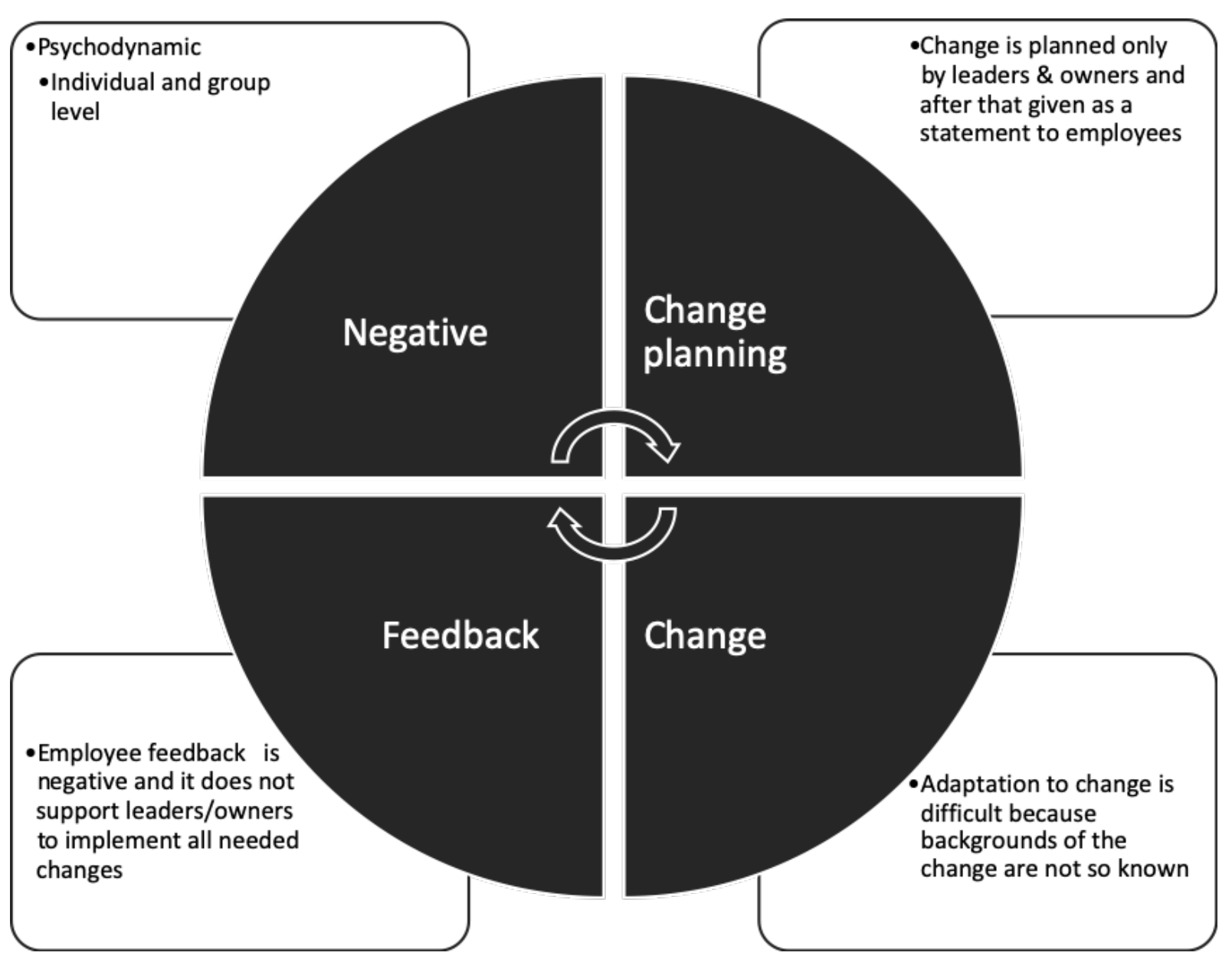

Figure 5. Negative psychodynamic loop

When the psychodynamic loop in the family firm is negative (like in cases $1 \& 2$ ) it sets challenges for the predecessors and successors when it comes to implementing the family business succession (see figure 5). According to the results of this study, under a negative psychodynamic loop, members in the family firm concentrate on contributing to their own interest and defending gained privileges. From the viewpoint of employees, a negative psychodynamic loop means resistance to change and negative feedback to predecessors and successors. As in case 1, non-family employees saw that changes caused by succession threatened the firm and as a result, they sometimes ignored or resisted the changes and continued their daily work in their usual way.

\section{Conclusions}

In small family firms, where cooperation and interaction between people is very close and frequent, changes in the way individuals behave and think impact on other members in the firm. It can also be seen how important it is to inform non-family employees about a family business succession i.e. what it really means and what kind of changes it will bring along. The results of this study suggest that when non-family employees are active participants in succession process, they can affect the timing, direction and ultimately level of success of the succession.

Compared to Kellermanns \& Eddleston (2004) study, this study has shown some of the reasons why family business succession can lead to relationship conflict, effect the firm's performance and the succession implementation. Kellermanns \& Eddleston (2004) argues that the effects of conflict on performance cannot be completely understood without taking into account the relationship among family members. This study has shown that it is critically important is to understand the reasons for conflict as well as the behaviours and relationships of non-family employees. As one of theoretical conclusions has stated, stakeholder theory could be better integrated as part of family business succession research.

The results of this study indicate theories about effective succession implementation have overlooked one of main aspects that influence succession especially when it comes to small family firms. This study has shown that non-family employees can affect how successions are implemented in a family business (cf. Dyck, Mauws, Starke, \& Mischke, 2002; Le Breton-Miller, Miller \& Steier, 2004; Kets de Vries, 1996; Handler 1994; Miller, Steier \& Le Breton-Miller, 2006; Habbershon \& Williams, 
1999). Based on results, this study has presented an improved version of Handlers four step model in this paper (Figure 3). This study has shown that changes in employees' psychodynamics can have significant impact on their behaviour within their working environment, which in turn can influence others (knock-on effect). For family business owners it is not often clear how their employees will accept a business succession and that is why in succession theories and in terms of practical implementation, the non-family employee perspective should be included more widely. According to the results outlined in this study, from the viewpoint of non-family employees, family business succession is not about clear steps to be taken but more like a smooth transition from predecessor to successor (cf. Handler, 1994; Cater \& Justis, 2009).

According to the results of this study, from the perspective of the employees' psychodynamics, trust is one of the key elements in the succession process. A change of leader forces employees to rebuild their trust as dyadic trust in the new leader. Employees' dyadic trust is combined with organisational trust; so in cases where an employee has to rebuild the dyadic trust in the leader it happens first and as a result guides the direction in which organisational trust will develop. A key element in the rebuilding of trust is the perception employees have about the leader's behaviour in the organisation and the kinds of actions that will take place in the organisation on a daily basis. Open communication, including all members within an organisation, regardless of whether they are a family member or not, supports the development of dyadic trust and, if possible, non-family employees should be brought along as listeners to family meetings where decisions are taken.

This study illustrates two practical implications, firstly the importance of open communication and interaction. This study has shown that where non-family employees can participate in decision making, the family firm has a greater chance of success around succession (cf. Waddel \& Sohal, 1998). It is important for employees to present their ideas around issues in firms and that they are informed about what changes are coming and when those changes will be implemented. These issues directly affect the employees' commitment to a firm and the firm's future and have an impact on work motivation and work wellbeing.

The second practical implication is the importance of the relationship between actions and information. In the context of family business succession and employee psychodynamics, this study has confirmed previous theoretical findings around how trust is formed. For instance, people in organisations compare actions and the information they were given, if there is a disparity it can lead to a loss of trust, even suspicion, on the other hand, when actions match information given the opposite can occur. (cf. Good, 1988; Costigan et al., 1998; McCauley \& Kuhnert, 1992). The period around succession can often be quite uncertain for employees, when information is followed by action consistent with that information, then the employees mind and thinking is reassured and supported. Properly timed information that can be trusted reduces an employee need to collect information from their working environment and therefore prevent them from using unofficial observations as the basis for unwelcome assumptions that can be very damaging for the implementation of the succession process.

This research paper has some limitations, the most important of which concerns the case study method. Firstly, the results from the case studies cannot be generalized to some wider scenario or if so, only with extreme care. Secondly this study has its own context and the results cannot be applied outside of this context (Welch, et al. 2011). As a concept, psychodynamics is very broad and over the years, scholars have presented many different perspectives, which have further broadened it as subject. In this study, psychodynamics is applied from a modern perspective which highlights its influence on individual behaviour and interactions within a business environment i.e. the results of this study are only connected to this modern perspective of psychodynamics while the broadening outside of this limitation in not advisable. A further limitation of this study lies in interviews having been conducted in a confined geographic area (i.e. Finland), which raises the issue of cultural differences in other countries. Because the nature of this study has been explorative and so to reveal new interesting phenomenon from real world. In the future it is most recommendable to study further the results of this study by wider quantitative study and in other cultures.

This study has shown how important communication and the participation of all those involved, directly and indirectly, is for the success of the family business succession and the future of the family firm. Open communication and interaction require trust from all participants. The changes that arise around the family business succession is a time which can challenge trust. Up to now, studies have focused on the appearance of trust in family businesses generally and the moment of family business succession, however, few studies exist from the non-family employees' perspective, which is important to study, because as shown in this study, non-family employees influence have an important influence and part to play around family business succession. Scholars have presented many models on how to implement family business succession effectively (Royer, Simmons, Boyd \& Rafferty, 2008; Le Breton-Miller, Miller \& Steier, 2004; Handler, 1994). In the future, the non-family employee experience and influence around succession it should be studied with the aim of seeing how it can inform and improve this important process. As this study has concentrated on successions in small family firms, it would be worth focusing on larger family firms at the time of succession especially family businesses where there is more than two organisational levels as it is possible that 
employees' experiences will present differences from the smaller family firms.

\section{REFERENCES}

[1] Albarracin, D. \& Kumkale, G.T. (2003). Affect as information in persuasion: A model of affect identification and discounting. Journal of Personality and Social Psychology, 84(3): 453-469.

[2] Anand, S., Vidyarthi, P.R., Liden, R.C., \& Rousseau, D.M. (2010). Good citizens in poor-quality relationships: Idiosyncratic deals as a substitute for relationship quality. Academy of Management Journal, 53(5): 970-988.

[3] Anderson, H. \& Goolishian, H. (1992). The Client is the Expert: A Not-Knowing Approach to Therapy. In McNamee, S. \& Gergen, K.J. (eds.) Therapy as Social Construction. (pp. 25-39). London: Sage Publications Ltd.

[4] Baars, B.J. \& Gage, N.M. (2010). Cognition, brain, and consciousness: Introduction to cognitive neuroscience. Amsterdam: Academic Press.

[5] Barach, J. \& Ganistky, J. 1995. Successful succession in family business. Family Business Review, 8(2): 131-155.

[6] Battilana, J. \& Casciaro, T. (2012). Change agents, networks, and institutions: A contingency theory of organizational change. Academy of Management Journal, 55(2): 381-398.

[7] Beck A.T. (1985). A cognitive model of anxiety formation and anxiety resolution. Issues in Mental Health Nursing, 7(1-4), 349-365.

[8] Bernstein, D.M., Erdfelder, E., Meltzoff, A.N., Peria, W. \& Loftus, G.R. (2011). Hindsight Bias from 3 to 95 Years of Age. Journal of Experimental Psychology: Learning, Memory, and Cognition, 37(2): 378-391.

[9] Blank, H., Nestler, S., von Collani, G. \& Fischer, V. (2008). How Many Hindsight Biases Are There? Cognition, 106(3): 1408-1440.

[10] Brearley, J. (2007). A Psychodynamic approach to social work. In Lishman, J. (ed.) Handbook for Practice Learning in Social Work and Social Care: Knowledge and Theory. ( $2^{\text {nd }}$ Edition. pp. 48-63). London: Jessica Kingsley Publishers.

[11] Brewin, C.R. (1996). Theoretical foundations of cognitive-behavior therapy for anxiety and depression. Annual Review of Psychology, 47(1): 33-57.

[12] Brockhaus, R.H. (2004). Family Business Succession: Suggestions for Future Research. Family Business Review, 17(2): 165-177.

[13] Brown, A.D. \& Starkey, K. (2000). Organizational identity and learning: A psychodynamic perspective. Academy of management Review, 25(1): 102-120.

[14] Cater, J.J. III. \& Justis, R.T. (2009). The Development of Successors from Followers to Leaders in Small Family Firms. An Exploratory Study. Family Business Review, (22)2: 109-124.
[15] Chrisman, J.J., Chua, J.H., \& Steier, L.P. (2002). The influence of national culture and family involvement on entrepreneurial perceptions and performance at the state level. Entrepreneurship Theory and Practice, 26(4): 113130.

[16] Chua, J.H., Chrisman, J.J., \& Sharma, P. (1999). Defining the family business by behaviour. Entrepreneurship Theory and Practice, 23(4): 19-39.

[17] Chua, J.H., Chrisman, J.J. \& Sharma, P. (2003). Succession and nonsuccession concern of family firms and agency relationships with non-family managers. Family Business Review, 16(2): 89-108.

[18] Clarke, J.B. (1999). Hermeneutic analysis: a qualitative decision trail. International Journal of Nursing Studies, 36(5): 363-369.

[19] Collins, L. (2011). To succeed or not to succeed: A multiple perspectives literature review of research in family business succession. In: IFERA 2010, 28th June-1st July, 2011, Sicily.

[20] Costigan, R.D., Ilter, S.E. \& Berman, J.J. (1998). A multi-dimensional study of trust in organisations. Journal of Managerial Issues, 10(3): 303-317.

[21] Cushman, P. (1990). Why the Self Is Empty. American Psychologist, 45(5): 599-611.

[22] Davis, P.S. \& Harveston P.D. (1998). The Influence of Family on the Family Business Succession Process: A Multi-Generational Perspective. Entrepreneurship Theory and Practice, 22(3): 31-53.

[23] Delmar, F. \& Davidsson, P. (2000). Prevalence and Characteristics of Nascent Entrepreneurs. Entrepreneurship and Regional Development, 12(1): 1-23.

[24] Dyck, B., Mauws, M., Starke, F.A. \& Mischke, G.A. (2002). Passing the baton: The importance of sequence, timing, technique and communication in executive succession. Journal of Business Venturing, 17(2): 143-162.

[25] Easton, G. (2010). Critical realism in case study research. Industrial Marketing Management, 39(1): 118-128.

[26] Frijda, N.H. (1986). The emotions. Cambridge, UK Cambridge University Press.

[27] Fruggeri, L. (1992). Therapeutic Process as the Social Construction of Change. In McNamee, S. \& Gergen, K.J. (eds.) Therapy as Social Construction. (pp. 40-53). London: Sage Publications.

[28] Gersick, K.E., Davis, J.A., Hampton, M.M., \& Lansberg, I. (1997). Generation to generation: Life cycles of the family business. Boston, MA: Harvard Business School Press.

[29] Good, D. (1988). Individuals, Interpersonal relations, and Trust. In Gambetta, D.G. (ed.) Trust: Making and Breaking Cooperative Relations. (pp. 131-185). New York: Basil Blackwell.

[30] Habbershon, T.G. \& Williams, M.L. (1999). A Resource-Based Framework for Assessing the Strategic Advantages of Family Firms. Family Business Review, 12(1): 1-25. 
[31] Handler, W.C. (1994). Succession in Family Business: A Review of the Research. Family Business Review, 7(2): 133-157.

[32] Hayek, F.A. (1952). The Sensory Order: An Inquiry into the Foundation of Theoretical Psychology. Chicago: The University of Chicago.

[33] Howe, D. (2002). Psychosocial Work. In Adams, R., Dominelli, L. \& Payne, M. (eds.) Social Work. Themes, Issues and Critical Debates. $2^{\text {nd }}$ ed. (pp. 170-179). Pasingstoke: Palgrave in association with the Open University.

[34] Håkonsson, D.D., Burton, R.M., Obel, B. \& Lauridsen, J. (2008). How failure to align organizational climate and leadership style affects performance. Management Decision, 46(3): 406-432.

[35] Jonides, J., Lacey, S.C. \& Nee, D.E. (2005). Processes of Working Memory in Mind and Brain. Current Directions in Psychological Science, 14(2), 2-5.

[36] Josephson, J. R. \& Josephson, S. G. (1996). Abductive Inference. Computation, Philosophy, Technology. Cambridge University Press.

[37] Ignatius, E. \& Kokkonen, M. (2005). Viisi suurta persoonallisuuden piirrettä luottamuksen ja itsetunnon selittäjinä. Psykologia, Vol. 40, No. 2, 133-144. (In Finnish only)

[38] Kalimo, R. and Toppinen, S. (1999). Organisational well-being. Ten years of research and development in forest industry corporation. In Cooper, C. L. and Kompier, M. (ed.) Preventing Stress, Improving Productivity - European case studies in the workplace (pp.52 - 85). London. Routledge.

[39] Kellermanns, F.W. (2005). Family Firm Resource Management: Commentary and Extensions. Entrepreneurship Theory and Practice, 29(3): 313-319.

[40] Kets de Vries, M.F.R. (1996). Family Business: Human Dilemmas in the Family Firm. London: International Thomson Business Press.

[41] Kets de Vries, M.F.R., Vrignaud, P., Korotov, K., Engellau, E., \& Florent-Treacy, E. (2006). The development of the Personality Audit: a psychodynamic multiple feedback assessment instrument. International Journal of Human Resource Management, 17(5): 898-917.

[42] Kohut, H. (2009). The Restoration of the Self. (orig. 1977) Chicago: The University of Chicago Press.

[43] Kyrö, P. \& Kansikas, J. (2005). Current state of methodology in entrepreneurship research and some expectations for the future. In Fayolle, A., Kyrö, P. \& Uljin, J. (eds.) Entrepreneurship Research in Europe: Outcomes and Perspectives. (pp. 121-149). Cheltenham: Edward Elgar Publishing Limited.

[44] Lazarus, R.S. \& Folkman, S. (1984). Stress, appraisal, and coping. New York: Springer.

[45] Le Breton-Miller, I., Miller, D. \& Steier, L.P. (2004). Toward an Integrative Model of Effective FOB Succession. Entrepreneurship Theory and Practice, 28(4): 305-328.

[46] Maiteny, P.T. (2002). Mind in the Gap: summary of research exploring 'inner' influences on pro-sustainability learning and behavior. Environmental Education Research, 8(3): 299-306.

[47] McCauley, D.P. \& Kuhnert K.W. (1992). A Theoretical review and Empirical Investigation of Employee Trust in Management. Public Administration Quarterly, 16(2): 265285.

[48] Meyer, K. \& Damasio, A. (2009). Convergence and divergence in a neural architecture for recognition and memory. Trends in Neurosciences, 32(7): 376-382.

[49] Miller, D., Steier, L. \& Le Breton-Miller, I. (2003). Lost in time: intergenerational succession, change, and failure in family business. Journal of Business Venturing, 18(4): 513531.

[50] Miller, D., Steier,L. \& Le Breton-Miller, I. (2006). Lost in Time: intergenerational succession, change and in family business. In Poutziouris, P.Z., Smyrnios, K.X. \& Klein, S.B. (eds.) Handbook of Research on Family Business. (pp. 371387). Cheltenham: Edward Elgar Publishing Ltd.

[51] Mintzberg, H. (1994). The rise and fall of strategic planning. New York: The Free Press.

[52] Molly, V., Laveren, E. \& Deloof, M. (2010). Family business succession and its impact on financial structure and performance. Family Business Review, 23(1): 131-147.

[53] Morris, M.H., Williams, R.O., \& Nel, D. (1996). Factors influencing family business succession. International Journal of Entrepreneurial Behaviour \& Research, 2(3): 68-81.

[54] Myers, M.D. (1997). Qualitative Research in Information Systems. Mis Quarterly, 21(2): 241-242.

[55] Nadkarni, S. \& Herrmann, P. (2010). CEO personality, strategic flexibility, and firm performance: the case of the Indian business process outsourcing industry. Academy of Management Journal, 53(5): 1050-1073.

[56] Nestler, S., Blank, H. \& Egloff, B. (2010). Hindsight [not equal to] Hindsight: Experimentally Induced Dissociation Between Hindsight Components. Journal of Experimental Psychology: Learning, Memory, and Cognition, 36(6): 1399-1413.

[57] Ortony, A., Clore, G.L. \& Collins, A. (1988). The cognitive structure of emotions. Cambridge, UK: Cambridge University Press.

[58] Payne, M. (2005). Modern Social Work Theory. $3^{\text {rd }}$ ed. Chicago: Lyceum Books, Inc, cop.

[59] Piaget, J. (1926). The language and thought of a child. London: Routledge \& Kegan Paul.

[60] Piaget, J. (1930). Child's Conception of Physical Causality. Florence: Routledge.

[61] Royer, S., Simons, R., Boyd, B. \& Rafferty, A. (2008). Promoting Family: A Contingency Model of Family Business Succession. Family Business Review, 21(1): 1530.

[62] Ruggieri, R., Pozzi, M., \& Ripamonti, S. (2014). Italian Family Business Cultures Involved in the Generational 
Change. Europe's Journal of Psychology, 10(1): 79-103.

[63] Saariluoma, P., Kamppinen, M. \& Hautamäki, A. (2001). Moderni kognitiotiede. Helsinki: Gaudeamus.

[64] Salvato, C., \& Corbetta, G. (2013). Transitional leadership of advisors as a facilitator of successors' leadership construction. Family Business Review, 26(3): 235-255.

[65] Savolainen, S. \& Kansikas, J. 2013. Non Family Employees in Small Family Business Succession: The Case of Psychological Ownership. World Review of Entrepreneurship, Management, and Sustainable Development, 9(1): 64-81.

[66] Sayer, A. (1992). Method in social sciece: A realist approach. $2^{\text {nd }}$ ed. London: Routledge.

[67] Schneier, C.E. (1974). Behavior Modification in Management: A Review and Critique. Academy of Management Journal, 17(3): 528-548.

[68] Schwarz, N. \& Clore, G.L. (1983). Mood, misattribution, and judgments of well-being: informative and directive functions of affective states. Journal of Personality and Social Psychology, 45(3): 513-523.

[69] Solso, R.L. (1979). Cognitive psychology. New York: under the general editorship of Jerome Kagan.

[70] Sonfield, M.C. and Lussier, R.N. (2009). Non-family-members in the family business management team: a multinational investigation. International entrepreneurship and management journal, 5(5): 395-415.

[71] Snow, R.E., Corno, L. \& Jackson, D. (1994). Individual Differences in Conation: Selected Constructs and Measures. In Berliner, D.C. \& Calfee, R.C. (eds.) Handbook of Educational Psychology. (pp. 243-310). New York: Simon \& Schuster Macmillan.

[72] Tang, Y.-Y. \& Posner, M.I. (2009). Attention training and attention state training. Trends in Cognitive Sciences, 13(3): 222-227.

[73] Upton, N., Teal, E.J., \& Felan, J.T. (2001). Strategic and business planning practices of fast growth family firms. Journal of Small Business Management, 39(1): 60-72.

[74] Vince, R. (2011). The spatial psychodynamics of management learning. Management Learning, 42(3): 333347.

[75] Waddel, D. \& Sohal, A.S. (1998). Resistance: a constructive tool for change management. Management Decision, 36(8): 543-548.

[76] Walton, D. N. (2007). Dialogue Theory for Critical Argumentation. Philadelphia. John Benjamins Publishing Company.

[77] Welch, C., Piekkari, R., Plakoyannaki, E. \& Paavilainen-Mäntymäki, E. 2011. Theorising from case studies: towards a pluralist future for international business research. Journal of International Business Studies, 42(5): $740-763$.

[78] Yin, R.K. (1994). Case study research: Design and methods. California: Sage. 